\title{
Speak up for health
}

\author{
Fiona Godlee editor in chief
}

The BMJ

It shouldn't be news to anyone that air pollution causes disease, disability, and death, but this week we add new causes and costs to the charge sheet. Yaguang Wei and colleagues reviewed data from over 95 million US Medicare claims, harvesting a long list of conditions and huge costs associated with short term exposure to airborne particulates (doi:10.1136/bmj.16258). These associations remain even at levels of pollution below the World Health Organization's guideline. This confirms the view that there is no safe lower limit, say our editorialists (doi:10.1136/ bmj.16609).

Other research this week reinforces what most of us think: that the UK's NHS is underfunded. Irene Papanicolas and colleagues find that though the total spending is level with the OECD and EU averages, it is lower than the average for rich countries such as Australia, Canada, and Denmark - and the gap is widening. The NHS achieves similar levels of access, despite fewer doctors and nurses per head, but has poorer outcomes and health status than its European and North American peers.

With the NHS polling as the most important election issue for between half and two thirds of voters, this is crucial information. We've summarised the three main parties' funding and other health promises (doi:10.1136/bmj.16702), and our columnist Andy Cowper gives his verdict (doi:10.1136/bmj.16673), most damningly of the Conservatives' "magical warehouse of doctors, nurses and GP appointments."
Those working at the front line will be all too aware of the mounting pressures. Under such circumstances, can you really still improve quality? Yes, says Joanna Bircher (doi:10.1136/ bmj.16594). She suggests starting with why. "If people have a strong sense of purpose and know why they do what they do, they will notice when current performance isn't delivering their aspirations," she says. Maintaining enthusiasm for what you do could also stop you becoming a "heartsink doctor," says Jonathan Glass (doi:10.1136/bmj.16660). And if you are in search of a lasting role model, look no further than Eric Beck (doi:10.1136/bmj.16220), a passionate advocate for social justice and equality and the principles of the NHS.

But keeping going doesn't mean keeping quiet. Ingrid Torjesen assures us that, despite the purdah imposed before a general election, it's fine to express views on issues such as healthcare funding and air pollution (doi:10.1136/bmj.16679). In fact this is when we most need to speak out, says David Oliver (doi:10. 1136/bmj.16620). "We're in the middle of a general election campaign, so we must blow the whistle loudly ... and make politicians and national service leaders listen."

Finally, this week we launch our annual Christmas charity appeal. This year we ask readers to support WaterAid, which brings clean water, toilets, and hygiene to the world's poorest people (doi:10.1136/bmj.16703). 